\title{
STRATEGIES FOR IMPROVING SUPERVISORY SKILLS FOR EFFECTIVE PRIMARY EDUCATION IN NIGERIA
}

\author{
ENAIGBE A. PATRICK \\ College of Education, \\ Ekiadolor, Benin \\ P.M.B 1144 \\ Benin City
}

\begin{abstract}
Primary education in Nigeria is of paramount importance to the attainment of personal and national development. This opinion necessitated this paper, as it relates to the need for improved supervisory skills by education personnel towards achieving the goals of primary education in Nigeria. This paper clarifies certain basic concepts such as inspection and supervision, the responsibility of supervisors, relevant areas in supervision, the challenges of supervisors as well as strategies for acquiring improved supervisory skills. Recommendations are made for ensuring the attainment of superior supervisory skills at the primary school level.
\end{abstract}

\section{Introduction}

The crucial role of primary education in both personal and national development informed the introduction of various educational programmes aimed at enhancing primary education in Nigeria and in other parts of the world. In Nigeria, such programmes include the Universal Primary Education (UPE) in 1976 and the Universal basic Education (UBE) in 1999.

The goals of primary education as stated in the National Policy on Education (2004) include the following:

a. To inculcate permanent literacy and numeracy and the ability to communicate effectively.

b. Lay a sound basis for scientific and reflective thinking

c. Give citizenship education as a basis for effective participation in and contribution to the life of the society.

d. Mould the character and develop sound attitude and morals in the child.

e. Develop in the child the ability to adapt to his changing environment. 
f. Give the child opportunities for developing manipulative skills that will enable him to function effectively in the society within the limits of his capacity.

g. Provide the child with basic tools for further educational advancement, including preparation for trades and craft of the locality.

The document further stated that the curriculum for primary education shall include among others; language, i.e. English, French and language of the environment, mathematics, science, physical and health education, religious knowledge, agricultural science, home economics, social studies, citizenship education, cultural and creative arts, etc.

A careful consideration of the above goals and curriculum content brings to the fore the need for a well-balanced and result-oriented teaching and learning process as well as interaction between and among students, teachers, school leaders and external education officials. One of such organized and structured interaction is the supervision of instruction and other relevant educational activities and school facilities by school heads or other designated officials. The discharge of this task cannot be left to chance or in the hands of unqualified, out-dated, or untrained education personnel.

This paper therefore attempts to highlight the need to enhance the skills of those saddled with the responsibility of carrying out school supervision in our primary schools in order to ensure quality of instruction necessary for the attainment of national objectives for primary school education in Nigeria.

\section{Definition of Concepts}

There seems to be confusion in the meaning of supervision and inspection. There is the need to clarify these concepts.

To inspect means to investigate, find fault, ascertain that all is in line with expected standards. It also means to examine a thing carefully or critically. It could also mean to examine officially on visit to make sure that rules and standards are being observed.

On the other hand, according to Igwe (2001), to supervise means to direct, oversee, guide or to make sure that expected standards are met. Thus, supervision in a school implies the process of ensuring that principles, rules, regulations and methods prescribed for purposes of implementing and achieving the objectives of education are effectively carried out. Supervision therefore involves the use of expert knowledge 
and experiences to oversee, evaluate and coordinate the process of improving teaching and learning activities in schools.

Furthermore, supervision could be seen as an interaction involving some kind of established relationship between and among people, such that people influence people. Such interactions are greatly influenced by a predetermined programme of instruction. In this regard, and according to Netzer and Kerey (1971), the systematization of the interaction of those responsible for operating within the structure of administration is called supervision. Thus, the supervisor is expected in the course of his duty, to initiate several activities that will lead to a successful merging of these two contexts in order to achieve harmony and satisfaction.

\section{Skills Required for Supervision}

A lot of professional skills are required for supervision in schools. According to Olowoye (1989), these skills can be classified into eight major groups as stated below:

1) Pedagogical Skills: These include mastery of subject matter, teaching methods, improvisation, presentation of content, preparation of lesson notes, lesson plans and units etc.

2) Evaluation Skills: These include questioning, continuous assessment and examination skills.

3) Disciplinary Skills: These include class control, punishment, use of rules and regulations and maintenance of order.

4) Motivational Skills: Issues bordering on rewards and reinforcement are emphasized.

5) Reportorial Skills: Documentation of report card, class register, log book, attendance book etc.

6) Managerial Skills: These are skills on time management, good use of teaching aids, difficult situation, and students behaviour.

7) Interactive Skills: Creation of rapport, teacher's personality and general characteristics, cooperation etc.

8) Analytical Skills: Possession of mathematical ability, statistical computation and interpretation of data etc.

The importance of acquiring these skills cannot be left to chance or in the hands of charlatans or mediocre. This informs the need to improve on the skills of school supervisors in order to achieve the objectives of primary education in Nigeria.

Duties of School Supervisors

In a nutshell, the responsibilities of the heads supervisors could be outlined as follows

According to Guynm (1981) 
1. Helping teachers and stimulating curriculum improvement

2. Emphasizing the use of group process with teachers, students and other school personnel.

3. Performing administrative functions only to help instructions through in-service.

4. Teaching of teachers for improving instruction through inservice.

Igwe (2001) noted that supervision involves evaluation, monitoring and quality control for the purpose of curriculum and infrastructural development and improvement. In order to achieve this, some specific tasks of the supervisor in a modern school have been identified and listed here under;

a) Helping school head teachers to understand students better

b) Helping teachers and individuals for professional growth

c) Acquiring cooperating spirit for team work

d) Making better use of teaching materials

e) Improving methods of teaching

f) Improving teacher's appraisal of his standards

g) Acquisition of originality for the teacher within the commodity.

h) Faculty plan for curriculum improvement

The common denominator in the objectives of supervision as outlined above is to help teachers become more effective in planning their class work in terms of utilizing maximally, textbooks and other basic materials and curricular aids as well as helping teachers with guidance and evaluation.

\section{What to Supervise}

Effective intra-school supervision is based on identifying certain criteria areas that if well supervised, would help improve the quality of primary school education in Nigeria.

Afolabi and Loto (2008) identified, among others, the following areas:

\section{i. The Nature of Lesson Plan}

The lesson plan is a reflection of the level of preparedness as well as the effort the teacher made in gathering information for the lesson. So a poorly written lesson plan not only indicates the quality of the teacher, but also the level of commitment to his primary task of teaching. The school head (principal) must critically examine the following items of the lesson plan: 
a) The clarity and appropriateness of the learner behavioural objectives

b) The relevance and adequacy of the lesson notes,

c) Selection of appropriate teaching aids,

d) Selection of appropriate evaluation techniques to determine the extent of realizing the objective effectively.

\section{ii. Lesson Presentation}

Teaching is said to be effective if the desired objectives are achieved. The school principal is required to carefully pay attention to the following areas:

a) The introduction of the lesson and the teacher's ability to maintain students' attention throughout the duration of the lesson,

b) The teacher's voice quality, speech, clarity of expression, intelligibility and appropriateness of language, effective use of learning materials such as audio-visual aids and chalkboard, etc.,

c) Teacher's knowledge of the subject matter in terms of structure and sequence,

d) Use of classroom management techniques including skills in affecting student's participation in class activities.

\section{iii.Reference Materials}

The use of appropriate reference materials such as textbooks, scheme of work and syllabus cannot be overlooked. The principals must look into the following:

a) The duration of item or topic.

b) The relevance and logicality of the materials used,

c) The sequence of presentation of contents, etc.,

d) Use of current as opposed to obsolete materials.

\section{iv. The Relationship between Teacher and Student}

Without doubt, a harmonious interpersonal relationship between teachers and students could engender learning and attainment of educational goals. In this regard, the principal must seek for genuine love and concern, positive and acceptable disposition between and among the teachers and students. His ability to accommodate or tolerate and, if possible, lend a helping hand through guidance and counseling services must be considered. 


\section{v. Classroom Management}

Effective classroom management facilitates teaching and learning process. The principal or other appointed school personnel must be conversant with the following:

a) Ability to discipline and control students,

b) Reward skills to reinforce good performance or conduct,

c) Ability to identify cases and causes of students mis-behaviour,

d) Creation of conducive classroom climate,

e) Sitting arrangement of students,

f) Classroom physical condition

\section{vi.Personality of the Teacher}

Teacher's personality includes among things his personal traits or characteristics, emotional status, appearance, intelligence, physique, leadership skills, communication skills, etc.

\section{Challenges of School Supervision}

There are several problems, which tend to militate against effective supervision of instruction in our schools.

Staff Inadequacy: The number of professionally trained supervisors in our schools is grossly inadequate to meet the needs of an effective and efficient programme of supervision. The population of students in the school has so exceeded the stipulated teacher/pupils ratio that all that most principals do in terms of instruction is to ensure that there are enough teachers to man the classes.

Shortage of External Supervisor or Inspectors: External supervisors and inspectors are usually Ministry of Education or Education Board officers specially assigned to access the level of compliance of school instructional activities with approved government standards. Unfortunately, this category of staff is usually in short supply due to the large number of government schools and teachers. According to Ogunu (2005) the consequence of this shortage of supervisory personnel is that most of the time, a lot of unprofessional practices are carried out in our schools to the detriment of the children.

Lack of Time: According to Ogunu (2005) secondary school principals are so weighed down by routine administrative burden that they hardly find time to visit the classrooms and observe how the teachers are teaching.

When principals give more time to correspondence with the 
Ministry of Education and its parastatals, community affairs, parents and a host of other visitors and in the process neglect their primary duty of overseeing instruction in the schools, we cannot expect good performance from students. Some unscrupulous teachers easily exploit the school head's neglect of supervision to achieve their selfish ambitions.

Inadequate Basic Instructional Materials: There can be no effective supervision of instruction without instructional materials. Experience has shown that most schools lack even the basic materials and equipment for teaching such as textbooks, chalkboard, decent classroom for students. Apart from such cases of nothing to supervise, there are others where the problems are lack of facilities and materials for the supervisor to use. External supervisors (inspectors) for example, often do not have transport facilities and writing materials to carry out their inspectoral duties.

Lack of Adequate Training and Orientation in Instructional Supervision: Many newly appointed principals are not given the necessary training and orientation to equip them with the skills they need to carry out their instructional supervisory functions. They manage through for years without understanding what instructional supervision entails and how to do it.

Fiscal Inadequacy: Lack of funds often results in head teachers' inability to organize in-house orientation and in-service programmes for their staff or travel out to other schools and resources centres to gain access to new developments in curriculum and instruction that could benefit their schools.

There is an urgent need for the government to provide adequate funds and the right calibre of personnel for the supervision of instruction in our schools if the goals for national development are to be realized.

\section{Strategies for Improving Supervisory Skills}

1. Training and retraining of supervisor: The training of new supervisors and the retraining of old ones should be taken seriously. Special training centers where experienced and practicing supervisors are available should be established for this purpose. This is important because the ideas of using old or obsolete techniques or method negate the spirit of the inspection of primary education. Supervisors could be sponsored to seminars and workshops or conference to update 
their knowledge and skills on modern and acceptable techniques of supervision.

2. Morale Boosting: Researches are replete with the relationship between motivation and performance of skills. If supervisors are properly motivated with available work materials such as stationery, transportation, conducive working environment and enhanced salaries and allowances the morale of the supervisor cold be boosted thereby affecting the skills.

3. Employment of supervisors with higher educational qualifications: Supervisors with higher qualifications are more likely to perform better in the field than those with lower qualification. According to Okoro (2004), education personnel with higher qualifications display more confidence in their workplace. In addition, they are more accessible to quality information, and adapt to changing occupational conditions than their counterparts with lower qualification, who are usually more indisposed and ill-equipped in adapting to modern changes.

4. International and inter-state exchanges: It is suggested that deliberate and government sponsored international and interstate exchange of supervisory personnel and experiences could boost the skills of supervisors. Countries with similar educational policies such as Ghana, Gambia or Sierra Leone could be involved in such exchange programmes. The purpose is to ensure cross-fertilization of ideas, and explore way of tackling similar problems or challenges.

5. Improved Selection Criteria for Supervisors: Supervision is a technical task that requires meticulous, firm and objective assessment. Therefore, those saddled with this responsibility should be carefully selected from among the available education personnel in the schools or state ministries of education.

A special aptitude test could be administered testing various aspect of candidates' personality to determine their suitability. This rigorous exercise, according to Obanya (2005), stimulates confidence, which is a necessary ingredient for skill acquisition and performance.

6. Disciplinary Action Against Unprofessional or Unethical Conduct ort Performance: In order to improve the skills of school supervisors appropriate sanctions should be leveled 
against any erring or deviant supervisor who tends to undermine the expected standard. A situation whereby mediocrity is exalted and standard sacrificed, while supervisors who excel in their assignment should be rewarded accordingly, either in kind or cash sanctioning unacceptable performance could serve as a deterrent to others.

7. Reward for Performance: Even though reward of various kinds has a way of boosting the morale of workers, it also has the capacity of instigating increased performance and development of quality skills. Therefore, supervisors with excellent performance should be rewarded accordingly in order to maintain, and if possible improve their skills.

\section{Conclusion}

The need to acquire relevant skills by those charged with supervisory role aimed at achieving the said goals of primary education cannot be undermined by any right-thinking citizen of Nigeria. Consequently, concerted efforts should be made towards providing improved skills acquisition strategies by concerned stakeholders in the educational sector. It is hoped that if the content of this presentation is given the desired attention, the quality of skills of primary school supervisors would be improved and the standard of education could be better for it.

\section{Recommendation}

In the light of the above, it is hereby recommended that;

i. Supervisory Personnel at the local, national and international levels should take their responsibilities seriously by engaging on educational activities that could enhance their skills. These include, among others, strategic seminars, workshops, regular visits and exchange programs pursuit of higher educational qualification, etc.

ii. Supervisors that excel in their assignment should be rewarded accordingly either in kind or cash.

\section{Reference}

Afolabi, F.O. \& Loto, A.B. (2008), The headmasters and Quality Control in Primary Education through Effective Intra school supervision in Nigeria. In Journal of Teachers Perspective (Jotep) Vol. 3 No. 2.4-25

Good, G.V. (1945) Dictionary of Education. New York: McGraw-Hill Book, Co. Inc 
Guynm, J.M. (1974), Theory and Practice of Supervision, Toronto: Dodd, Mead and Co.

Igwe, S.O. (2001) Supervision, Evaluation and quality control in Education in Nwagwu, N.A. Current Issues in educational Management in Nigeria, Ambik Press Ltd., Benin City:

NERDC (2004): National Policy on Education. NERDC Lagos: pp. 14-15.

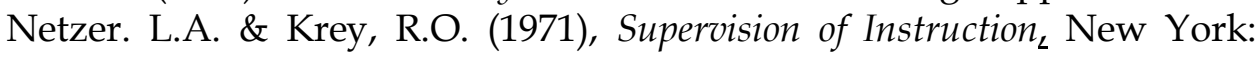
Harper and Bow

Obanya, R. A. (2005) Evaluation of School Performance in West Africa. Benin City: Ambik Press.

Ogunu. M.A. (2005) Introduction to Educational Management. Benin City: Mabogon Publisher

Okoro, N. J. (2004) The Role of Sex in Education Achievement. Journal of Teachers Perspective. Benin: Vol. 4(2) pp. 12-14.

Olawoge, K. O. (1989) Management of School Personnel. Ibadan: Mapo Publishing House. 